\title{
Refining Intractability: A Case Study of Entrapment in the Syrian Civil War
}

\author{
Siniša Vuković ${ }^{\mathrm{a}, \mathrm{b}}$ and Diane Bernabe ${ }^{\mathrm{a}}$ \\ a School of Advanced International Studies, The Johns Hopkins University, \\ 1740 Massachusetts Avenue, NW, Washington, DC 20036, USA \\ b Institute of Security and Global Affairs, Leiden University, The Hague, \\ The Netherlands \\ svukoviı@jhu.edu; s.vukovic@fgga.leidenuniv.nl; dbernabı@jhu.edu
}

Received 14 February 2019; accepted 25 April 2019

\begin{abstract}
Intractability is generally associated with prolonged tensions, employment of destructive means, suspicion and mistrust, inflammatory rhetoric and polarized solutions that are usually presented as ultimatums. Existing studies on intractability have emphasized the resistance to solution as a crucial indicator of intractability, and subsequently explored the phases through which intractability evolves and key characteristics these conflicts possess. What is largely missing is a nuanced explanation of at what point resistance turns into intractability. Building on earlier studies from social-psychology on entrapment in negotiations this article will develop a novel conceptual framework of entrapment as a precondition to intractability, and apply it to assess the causes and consequences of entrapment in an escalating conflict using the Syrian Civil War as a case study. The study will demonstrate that resistance to solution, which is a consequence of entrapment, does not automatically lead to intractability.
\end{abstract}

* Siniša Vuković, is Senior Lecturer and Associate Director of the Conflict Management Program, School of Advanced International Studies, Johns Hopkins University. He is also Visiting Assistant Professor at the Institute of Security and Global Affairs, Leiden University. His book, International Multiparty Mediation and Conflict Management (2015), was published with Routledge.

** Diane Bernabei is the Senior Academic Programs Coordinator at the Henry A. Kissinger Center for Global Affairs. Before joining the Center, she worked with Afghanistan's Permanent Mission to the United Nations headquarters in New York on foreign policy issues including negotiating the UN's Sustainable Development Goals and collaborating with UN agencies working in Afghanistan.

(C) SINIŠA VUKOVIĆ AND DIANE BERNABEI, 2019 | DOI:10.1163/15718069-24031191

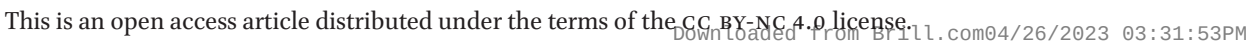




\section{Keywords}

entrapment - intractability - escalation - negotiation - mediation - Syria

On March 6, 2011 in the southern Syrian city of Daraa, a group of teenagers was arrested for spray-painting their school with words "it's your turn, doctor." ${ }^{1}$ Inspired by the wave of street protests that caused regime overthrow in Tunisia and Egypt, the slogan was a direct reference to the Syrian President Bashar AlAssad. Few days later, provoked by the arrests, a large crowd gathered in the center of Daraa, demanding the release of children from police custody and resignations from the mayor and the local chief mukhabarat (military intelligence) officer. The police forces opened fire on the demonstrators, killing six people in the process, and setting in motion the 'origin myth' of the Syrian civil war (NYT 2011; McEvers 2012; PRI 2015; Asher-Schapiro 2016). What started as a local matter quickly turned into an international proxy war with hundreds of thousands killed, millions fleeing to find refuge in neighboring countries, and even more internally displaced by the escalating violence (UNHCR 2017; H RW 2018). According to a World Bank report, by 2016 "the cumulative losses in gross domestic product (GDP) have been estimated at $\$ 226$ billion, about four times the Syrian GDP in 2010" (World Bank 2017). Rapid escalation of violence amplified sectarian divides, bringing to the fore sectarian framing of the conflict (Phillips 2015; Corstange \& York 2018). Hostile and inflammatory rhetoric used by all sides to mobilize public and international support quickly turned the country into a source of regional instability and a vulnerable breeding ground for terrorist activities (Jones 2013; Jenkins 2014). A series of failed peacemaking attempts and short-lived ceasefire arrangements reduced the appeal of a negotiated way out, adding to the perception that the only possible solution to the conflict is outright victory.

In light of such devastating consequences and their protracted nature, the conflict in Syria is labeled as intractable, both by media reporting $(B B C$ 2012; CNBC 2015; The Economist 2016), and the expert community (Miller 2014; Oosterveld 2018; Chulov 2018; di Giovanni 2019). The label even gained prominence among politicians and decision makers (Kerry 2015; European Parliament 2016; Burt 2018). During his last official press conference as the U.S.

1 A previous version of this research was presented at the 2019 ISA Annual Conference in Toronto. The authors would like to extend their gratitude to Govinda Clayton, I. William Zartman, and P. Terrence Hopmann for their invaluable comments and help at various stages of this research. 
President, Barack Obama defined the Syrian conflict as "one of the hardest issues of his presidency," and pointed out: Around the world as well, there are hotspots where disputes have been intractable, conflicts have flared up and people - innocent people - are suffering as a result, and nowhere is this more terribly true than in the city of Aleppo" (The Washington Post 2016).

While the term itself may have been used for stylistic purposes and primarily in a connotative way, a more denotative intention can be observed in the growing body of empirical studies (Grieg 2013; Lundgren 2016; Hinnebusch \& Zartman 2016; Erameh 2017; Rinne 2018). Intractable conflicts are generally associated with prolonged tensions, employment of destructive means, suspicion and mistrust, inflammatory rhetoric and polarized solutions that are usually presented as ultimatums. The persistent resistance to a negotiated solution has been identified as the crucial indicator of intractability (Zartman 2001; Coleman 2003; Walter 2003; Crocker et al. 2005; Hassner 2007). The track-record of defiance to peacemaking in Syria's civil war is stark: neither the UN-led Geneva process nor the subsequent (parallel) Russia-Turkey sponsored Astana process managed to bring parties to a negotiated agreement. Rather, participating delegations used every opportunity to express mutual disdain and fervidly reject proposed solutions. While such recalcitrance has led previous studies to treat the situation at hand as an intractable conflict, a more nuanced exploration of the actual reluctance to compromise may offer a better understanding of how resistance turns into intractability. Building on earlier studies from social-psychology on entrapment in negotiations, (Edmead 1971; Teger 1980; Brockner \& Rubin 1985; Rubin et al. 1994) this article will develop a conceptual framework of entrapment as a precondition to intractability.

First, this study aims to sophisticate scholarship's understanding of intractability by dissecting the phases of intractable conflicts that precede institutionalization and unpacking the psychological components to subjective decisions that underpin escalation in those phases. In so doing, it suggests entrapment and behavior leading to entrapping scenarios is a necessary condition to intractability. As such, its analysis posits that signs of entrapment can also be understood as warning signs of intractability and that, in recognizing these signs as windows of ripeness, solutions to manage entrapment and turn the course of conflict can be achieved. It proceeds by discussing current scholarship as it stands on the definition of intractability and the institutionalization of a conflict as well as these terms' necessary conditions as they are currently understood. It then analyzes entrapment as a phase of intractability. Finally, it uses the Syrian Civil War as an illustrative case of the phases of entrapment and how their consequences influence the trajectory of the conflict. 


\section{Analytical Framework}

\section{The Core Features of Intractable Conflicts}

Scholarly literature uses a wide range of terms to address conflicts that seem intractable, i.e. unmanageable and resistant to change (Coleman 2006; Kriesberg 2007). Similar to the notion of intractability, other labels such as "deeply rooted conflict" (Burton 1987), "protracted social conflict" (Azar 1990), and "enduring rivalries" (Goertz \& Diehl 1993; Diehl 1998) referred to situations characterized by protraction, identity polarization, and employment of destructive means as a way of imposing unilateral solutions. While each conflict maintains its own idiosyncrasies, there are several common features to each intractable conflict. First of all, they appear to persist for a long time. The relevance of protracted timeframe has less to do with an exact time-numerical threshold that has to be achieved for a conflict to become intractable, and more with the pervasive qualities of escalating conflicts. A lengthy conflict makes sunk costs not only an indication of parties' resolve, but also a tolerable - if not addicting - means of continuing commitment to intended objectives. Protraction feeds into narratives used to mobilize public support and justify a conflict's inevitability, its existentialist nature, and the need to maintain unyielding commitment to achieve outright victory. The longer they persist, the more conflicts get routinized by the public and imbedded in all spheres of social life. Kriesberg argues that protraction needs to go "beyond one social generation" in order for a conflict to achieve the quality of intractability, as this way "parties in conflict are likely to have learned and internalized reasons to continue their fight with each other" (Kriesberg 2005: 67).

The duration effect shapes parties' identities, making them more polarized and contingent upon dynamics of mutual demonization and dehumanization. Narratives of self-victimization are used to project the prevailing spirit of injustice caused by the other side, and are morphed into categorical loyalty to the group cause and unwavering commitment to maximalist unilateral solutions (Bar-Tal et al. 2009). Moreover, identities become rooted in extensive suspicion and fear about the other sides' intentions. This apprehension creates a sense of existential threat and negative interdependence; as Kelman explains "asserting one's group identity requires negating the identity of the other" (Kelman 1999: 581). The existential nature of intractable conflicts warrants enormous determination from the parties to vindicate any emerging cost and related burden from further conflict escalation. Since any type of compromise is automatically deemed as a sign of betrayal, or outright defeat, or less than a return on investments, the parties get stuck in a seemingly endless perusal of total victory. 
The parties' determination to achieve complete domination over the outcome is directly mirrored in their insistence to propose highly polarized solutions. Zartman notes that "the characteristic of existential, zero-sum identities hardens the parties' demands for their competing solutions" (Zartman 2005a: 53). Despite mounting costs and increasing pain, the parties remain unwilling to consider reframing their dispute and exploring a single consequential solution. Each party's perseverance showcases the parties' comfort with the status quo and a lack of urgency to look for alternative ways to achieve desired goals. For the parties, these conflicts are not just bearable, but actually gainful, especially for the elites that perceive the continuation of a conflict as a way to enhance their relevance and consolidate power. As a result, and to borrow from ripeness theory, intractable conflicts do not yield mutually hurting stalemates but, as Zartman refers to them, "soft, stable, self-serving stalemates" (Zartman 2005a: 52). In these conditions, these conflicts are not only useful for the parties (and most specifically for their decision-making elites), but actually predictable, even though to an outsider they may appear as destructive, painful, and unnecessary.

The mentioned predictability stems from a process that Coleman calls "normalization to hostility and violence," and argues that "biased construction of history, ongoing violent discourse, and intergenerational perpetuation of the conflict contribute to a sense of reality where the hostilities are as natural as the landscape" (Coleman 2006: 541). Violence becomes both useful and necessary mainly due to the prevailing perception that fresh investments, needed to sustain the conflict, make negotiations and related concessions very costly. In such conditions, as parties internalize antagonistic attitudes towards the other, in order to fully routinize violence and confrontational strategies, they start developing rules and norms on how to conduct their struggle. Kriesberg defines this as institutionalization of conflict, noting that "the rules make certain means of struggle legitimate, and as the authorities and others waging the struggle seem to support the rules and even punish dissenters, the rules increasingly constrain conduct" (Kriesberg 2005: 74).

Through this process the conflict develops a systemic dimension, as violence becomes more structural, imbedded into the new and existing institutional and legal frameworks (Galtung 1969). Institutionalization represents a distinctive feature of intractability: the ambition to regulate, codify and systematically organize conflict contributes to the process of socialization and acculturation of new generations into the fatalism that deems the conflict inevitable and existential, and presupposes everyone's readiness to contribute to the cause in the foreseeable future. Institutionalization can take different forms, and be present on different societal levels, from mandatory military 
conscription, to additional taxation in support of the cause, to youth trainings how to 'duck and cover', and other similar initiatives. Institutionalization represents the ultimate 'over-investment' in pursuing maximalist unilateral solutions. It significantly reduces the likelihood of a compromised solution, as any such solution would require a painstaking and very costly process of undoing the established conflict-supportive institutional framework and replacing it with a new compromise-oriented one. The longer such institutions were in place, the more their purpose and achievements have been internalized by the people, and as such the more they became an integral part of their identity and culture. Undoing them would not only be perceived as a sign of betrayal and capitulation, but as an existential threat aimed at changing the essence of the society itself.

\section{The Phases and Functions of Intractability}

Institutionalization implies parties' sense of comfort with, and acceptance of, a protracted conflict. Escalatory tools and tactics are still available to all parties, yet they are only sporadically employed, mainly for the purposes of signaling resolve to the cause. In fact, institutionalization represents the last phase of intractability, a culmination of previous escalatory measures that have shaped the relations between the parties, their goals and, most importantly, their identities. Intractable conflicts are most likely in situations that are characterized by legacies of injustices, ranging from ethnocentrism, to colonialism, racism, and other forms of human rights abuses (Azar 1990; Coleman 2006). Such past traumas and long-standing grievances remain a useful vehicle for mobilization at the disposal of political and intellectual elites (Volkan 1988). These collective memories achieve their full mobilizing potential following a dramatic event, and are often evoked through narratives that amplify saliency of identity (Gurr 2000). Such dramatic events may involve an 'agent provocateur' that incites a disproportionate reaction by the other side, echoing past traumas (King 2007). Even without such provocative action, a contentious episode may take place (i.e. a peaceful protest gets broken down in a highly violent manner, a political leader gets assassinated or imprisoned, a particular ethno-cultural group gets mistreated by authorities, etc.) that revives past traumas and sets in motion the need for retaliation (Kriesberg 2005). As Zartman notes, "in doing so, they turn old scars into new wounds, reaffirming history with new proofs and transforming momentary incidents into primordial hostility" (Zartman 2005a: 49).

Conflicts become intractable as parties resort to escalatory measures, develop confrontational and harmful strategies, and frame their goals as sets of seemingly irreconcilable issues (Kriesberg 2007). Escalation represents a qualitative and quantitative increase in conflictual dynamics (Rubin et al. 1994). 
It represents a specific type of intensification that causes change both in the degree and nature of a given conflict (Zartman 2005b). Escalation is a purposeful action enacted by parties with the aim of winning (or prevailing) over the other side, deterring the other side's confrontational capabilities and resolve, and justifying sunk costs of previous investments made with the aim of achieving unilateral solutions (Zartman \& Faure 2005: 6). Parties may also choose to escalate out of fear of failure, apprehension about previously miscalculated investments in means, or over-commitment to constituencies regarding the achievement of specific goals (Bowen 1987; Brockner 1992). Continued escalation may focus on causing further damage and harm to the other side, generating new grievances and accusatory rhetoric. As conflicts continue to escalate, identities become more entrenched, mutually exclusive and dominated by the sense of injustice caused by the other sides. Their goals become more exclusionary, complemented by previously unsettled issues, and frequently focused on destructive measures for the sake of retribution (Kriesberg 2005: 72).

For this reason, attempts to halt and reverse escalation through negotiation and/or mediation face substantial obstacles. Parties' over-commitment to the cause and the need to justify previous investments in reaching maximalist solutions reduce parties' optimism regarding a compromise solution (Pruitt 2005). Even when they signal readiness to negotiate they do it for strategically devious reasons, ranging from stalling, regrouping, rearming, and rallying domestic and international support for their cause (Richmond 1998). Lacking a sense of urgency to look for a compromise, parties resort to projections and public offers of their polarized solutions that they know will be unequivocally dismissed by the other side. As negotiated solutions lose their appeal, parties continue with their escalatory actions and rhetoric in order to signal unwavering resolve for the cause and mobilize further support for further intensification of conflict. Even occasional breakthroughs in peacemaking attempts, such as ceasefire agreements, may also fall short from full implementation as parties lack mutual trust and credible commitment to see the agreement through (Fortna 2003, Walter 2003). As a consequence, such agreements may incite further escalation, or normalize the conflict to the point of institutionalization.

\section{Causes and Consequences of Entrapment}

Before they reach the full character of intractability, exemplified by institutionalization of the conflict, parties commit tangible and intangible resources in pursuit of their goals, resorting to escalatory tactics in hopes of justifying sunk costs. The overconfidence in unilateral solutions, which warrants excessive investments in means to achieve them, breeds further escalation. Parties may believe that they can recover earlier investments by mobilizing more 
resources (Zartman \& Faure 2005: 9). In this sense, Fisher observes that "even though irrational by outside judgement, each party pursues its goals, believing that the ultimate reward is just around the corner and that only its attainment will justify what has already been expended. The longer mutual intransigence persists, the more parties feel compelled to justify their positions through continued intransigence" (Fisher 2006: 185). The dynamic where parties get stuck in the process of conflict intensification with no prospect of altering or reversing that trend is known as entrapment (Brockner \& Rubin 1985).

The concept was first developed by studies in social psychology, exemplified by the 'dollar auction game' where participants bid for a dollar on the condition that both the winner and loser have to pay their bids, even though only the winner may take the dollar (Shubik 1971; Teger 1980). In their desire to win over the other side, and not lose face, participants tend to extend the bidding even beyond the one-dollar mark, and as such, trap themselves in an upward spiral of over-committing. The only way out of this predicament, for the rational player, would be to stop at a certain point before the costs outweigh the expected benefits. Yet, in reality this dynamic exploits the irrationality of actors, who continue to bid to protect reputational costs and literal costs (O'Neill 1986; Leininger 1989).

Entrapment is a direct consequence of a continued conflict escalation. More importantly, it is the most pervasive quality of continued escalation. It is caused by "judgmental bias" where the need to recover previous investments becomes a more dominant motivation than that of achieving original aims (Zartman \& Faure 2005: 9; Mitchell 2005: 16). The psychological effect of entrapment breeds further escalation, as parties tend to resist perceiving previous costs as unbearable and burdensome, but rather necessary and justifiable. Past investments become imbedded in the process of rationalizing and normalizing conflict, as any form of compromise would undermine the over-commitment in reaching the outright victory. Political parties tend to avoid questioning past choices, which would otherwise undermine credibility and authority they built around their unyielding commitment to the cause (Cameron \& Quinn 1988). As such, further escalation becomes a vehicle for political face-saving and consolidation of public support.

The longer the conflict persists, and related investments toward outright victory are made, the less attractive a negotiated solution becomes. The elements of entrapment become obstacles to the conditions normally surrounding a mutually hurting stalemate and so parties to entrapping conflicts can fail to realize that calculated prospective costs outweigh gains (Zartman 2005a; Forde 2004). Mounting costs and increasing pain are not weighted against immediate returns, but against prospective (i.e. final or ultimate) gains. 
According Mitchell, entrapment goes through four distinct phases: 1) reward pursuit (i.e. focus on achieving potential rewards), 2) cost justification (i.e. justifying expenditures via further commitments), 3) punishment and loss minimization (i.e. increasing importance of goals aimed at punishing the adversary and minimizing overall loses), and 4) goal relinquishment (i.e. exhaustion of resources and search for a way out) (Mitchell 1991). His framework suggests that ripeness is most likely to manifest between phases three and four, when a major event can prompt the parties to reconsider their priorities and move from justifying previous investments to preserving the remaining resources through a redefined set of policy preferences. He argues that "parties need to become 'resource salvagers' rather than 'reward seekers' and become involved in a process of disengagement and de-commitment, saving the most they can, as rapidly as they can, from a clearly failed policy which offers little hope of achieving the original benefits for which it was originally launched" (Mitchell 1995: 43). This is the operable stage in entrapment. If parties exercise "resource salvager" behaviors, they are more apt to reach the institutionalization phase of intractability and it is more probable that the course of conflict will turn from intractable to solvable.

\section{Evaluation Framework for Entrapment}

Evaluating entrapment as an integral element of intractable conflicts warrants four distinct steps. First, it is crucial to understand the antecedent conditions and how these were shaped by escalating dynamics. Starting from the parties' initial perceptions, preferences and priorities, it is important to evaluate how parties valued their level of involvement and what variables they considered in their cost-benefit analysis when deciding whether to increase their commitment. Understanding the various benefits to making gains and protecting from losses is fundamental to explaining how and why external actors got involved and what propelled them to so consistently escalate their financial, human and reputational costs.

Second, by evaluating the chronology of key points and turning points that contributed to conflict escalation (Druckman 2005) the assessment may indicate when a given conflict becomes entrapping. In this respect, looking at the actual moves parties make, it is possible to assess how their willingness to commit to the conflict deepens over time. Our chronology follows the four distinct phases proposed by Mitchell's analysis of entrapment as an alternative to expected utility (Mitchell 1991).

Third, entrapment evidences itself in a "step-by-step growth of imbalance in power" (Meerts 2005). A clear way to measure this imbalance over time is to observe the shift in parties' commitment to their negotiation postures. The 
party that sacrifices the most control over negotiations, which Meerts uniquely posits is normally the "first party to move," not only also normally loses the most ground in a zone of possible agreement (ZOPA), but also the most net assets in the course of the conflict.

Fourth, for entrapment to fully manifest, it is essential to observe increased investments over time. Resistance to further escalation may be the first symptom of a party's intention to break away from entrapment in order to avoid getting stuck in an intractable conflict. Such unwillingness reduces the chances that parties accept further normalization of conflict and engage in the process of its incremental institutionalization. Without this process, escalating entrapment fails to push the conflict into full intractability, opening the possibility to halt and reverse the escalation process, allowing for ripeness to take shape.

Using the case of Syria, this article aims to look at how these underlining dynamics of the phases of entrapment can lead to either terminal intractability or opportunities for compromise. In decoupling the phases of entrapment from intractability, the article tries to further sophisticate the theoretical underpinnings of intractability and show that enduring intractability is only contingent upon the achievement of the institutionalization phase. As such, while a conflict is still going through entrapment, a possibility remains that this conflict can be ripened and the escalation spiral reversed.

\section{Syria's Civil War: A Case of Entrapment}

The following analysis of the Syrian civil war highlights the four phases of entrapment and the shifts in negotiation outcomes before and after the highwater mark of the war. It focuses mainly on the decisions of the states sponsoring on the ground combatants and seeks to measure the changes in their posture in negotiations throughout the war. The very first phase, that of reward pursuit is indicated by parties' "initial commitment" to a favored outcome, namely Russia and Iran openly supporting the Assad Regime and the United States and its European allies publicly backing the opposition (Mitchell 1991). The second phase, cost justification is characterized by decision-making bent on "proving political good sense of the previous investment and existing sacrifices" and is highlighted in a prolonged period of escalation (Mitchell 1991). A series of "crucial factors" that fundamentally changed the dynamic of the conflict in 2015 brought parties across a "particular threshold" that resulted in the emergence of "a more rational outlook" and sober decisions that led to de-escalation with the Assad regime in place (Mitchell 1991). On either side of these turning 
points negotiation outcomes remained stagnant only progressing as far as to reach humanitarian agreements on low-hanging non-political objectives.

\section{Antecedent Conditions: Identifying Bargaining Advantages}

For Assad's sponsors, Russia and Iran, maintaining influence in the region was paramount from the outset. Syria is Russia's last Cold-War "hold-out" in the Middle East, its only conduit into a larger sphere of influence allowing it access to precious energy resources, trading lines and lucrative customers for Russian exports (Landis 2017; Katona 2018). Iran similarly sees itself as a symbol of influence in Syria and the Assad government as a "rare and loyal ally" worth supporting (Esfandiary 2018). Its friendly and long-standing relationship with Syria served Iran in many ways, but most prominently with a direct path to Hezbollah, which had always allowed Iran to funnel military assistance and funding to its proxies in Lebanon and bolster its buffer with Israel. Both powers have long-term geostrategic interest in maintaining their influence over Syria.

Moreover, both parties made significant gains as a result of investing in maintaining this status quo which have, in turn, contributed to their calculus to increase their involvement. Both Iran and Russia see protecting their stronghold as a worthwhile trade-off for retaining the leverage they have gained in negotiations, especially the several peace efforts they spearheaded including the Astana Process and the Moscow conferences - efforts this case study perceives as opportunities to redistribute power in the region. For Iran, maintaining this clout puts it "in the same league" as other major players in the conflict (Esfandiary 2018), and for Russia it means governing the future of a new sphere of influence that puts it on the same, if not stronger footing, in the region as the U.S. Both Russia and Iran also see their control over Syria as vital to their national security interests, and have rooted somewhere in their anti-opposition positions a legitimate concern over the resurgence of Is Is and other radical elements that posed an increasingly serious threat to them at home as the Syrian crisis unraveled.

While Assad's sponsors had a lot to lose at the onset of the civil war, the Opposition and its supporters had a lot to gain. The U.S. never had a friendly relationship with the Assad government. American support for Israel from its conception, paired with its backing of four consecutive failed coup attempts in Syria, created an air of hostility between the U.S. and the Assad(s) regime that developed over the 2oth century into a thorny relationship (Landis 2017). The U.S. had imposed sanctions on Syria since the 1970s for its support of Hezbollah and its relationship with Iran, sanctions that it would raise again in 2003 when Syria opposed the U.S. invasion of Iraq (Sharp \& Blanchard 2011). The Syria-U.S. relationship, wrought with tension, created a context that made 
both pressuring Assad to step down and supporting the Opposition a natural policy-path to follow.

For the Opposition, toppling Assad was the only way out and for their backers - the EU, the U.S. and several Gulf states - supporting the rebels presented an opportunity to shape the conflict's outcome and to eclipse the other outside actors as Syria's main influencers once the dust settled. In the escalating conflict, the opportunity to defeat Assad's regime and replace his government with a U.S.-backed democracy that owed its success and existence to the western world and a few Gulf states seemed well worth the risk. However, the U.S. and other rebel backers underestimated the amount of support the Opposition would need upfront, perceiving Assad's fall to be imminent. They also overestimated their competence in negotiations, expecting Assad's sponsors to share in this notion that Assad was to face the same fate as the several other dictators that had fallen in the tides of the Arab Spring and to bend to their insistence that he step aside in favor of birthing a new government conceived of both their interests.

Identifying the reference point, or the status quo in international relations, is essential to understanding the framing of an issue and thus the posture of the decision-maker in deliberating his options (Levy 1994). According to prospect theory, if a power defending the status quo, such as Russia defending its influence on Syria, is threatened by a party that has relatively less to lose, in this case the U.S. sponsoring a defeated coalition of opposition forces, the status quo power will have a bargaining advantage (Jervis 1994). Moving the status quo is painful because it is harder for a state to adjust to a loss than to a gain, especially when the loss is a sacrifice like newfound legitimacy in the international community, control over negotiations or control over an anti-ISIS military campaign (Levy 1994).

In all of the possible prospects of different war scenarios in Syria, Russia, Iran and the Assad regime are the "players" most apt to leverage all of their available resources and take the most risks to keep from falling out of power. When confronted with impasses in negotiations, they are the ones more likely to pursue escalation on the ground as an alternative to a negotiated peace settlement, break ceasefires, instigate firefights and, in the case of Russia and Iran, increase the supply of weapons and financing in amounts disproportionate to the allied coalition's contributions when the regime appears to falter. Recognizing this asymmetry in what the war's sponsors are willing to invests is important to identifying under and over commitments in the early stages of entrapment. The party with more to lose adds more momentum in the later stages of the conflict whereas the party with less to lose underinvests in the conflict's initial phase of reward pursuit. 


\section{Phase One - Reward Pursuit: Identifying Goals and Making Bids, 2011-2012}

When evaluating the timeline of events and identifying the points of escalation, it is hard to say exactly when the Syrian conflict became entrapping and when each party became entrapped, but it is possible to point to the first movers and evaluate the strength of their initial commitments. In the most abstract terms, the U.S., in announcing that Assad must go, and the Opposition, in disturbing the status quo, were the "first movers" to indicate their willingness to commit to the conflict. In response to the uprisings, and eventually to the U.S. backing the opposition, the Assad regime and its state sponsors used the ample space above their adversaries' initial investments to raise their bids. These actions are illustrations of the first phase of entrapment, reward pursuit. Each party identified a goal and made a commitment towards achieving that objective.

President Obama made the so called "first move" on August 18, 2011 when he released a statement calling for Assad to step down, insisting "for the sake of the Syrian people, the time has come for President Assad to step aside" (White House 2011). The release concluded with a detailed overview of what Obama referred to as "unprecedented sanctions to deepen the financial isolation of the Assad regime," a threat, of sorts, that was likely conjured up to show Assad the U.S. was not willing to stand completely idle while he massacred his own people. The first bid was clear: the U.S. would take a position that plainly resonated with its ethos as a state but would not promise military support to the rebels or threaten Assad with intervention. In fact, Obama explicitly outlined in his statement the fact he "had heard" the Opposition's "strong desire that there not be foreign intervention in their movement" (White House 2011).

Declaring the U.S. position with such a weak show of support might have been initially perceived as and ultimately considered an underinvestment, but Obama did not see it that way. He believed the U.S. did not need to threaten military intervention at the beginning of the civil war, indicating first his resistance to the momentum of entrapment, and, second, a grave underestimation of what Syria's chapter of the Arab Spring would hold. He saw a higher bid as a play in the foreign policy establishment's "Washington playbook" which he claimed worked when the U.S. was threatened but "could also be a trap that [could] lead to bad decisions" if the U.S. was reacting to a scenario where it was not (Goldberg 2016). Indeed, the uprisings in Syria did not pose an immediate threat to the United States and so in Obama's initial calculus did not warrant the threat of military intervention. However, his call for Assad to step aside and his call's accompanying weak show of force not only threw U.S. commitment behind the opposition, but also left much imaginable space for Assad and his 
external backers to "counter-bid" on their desired outcome. The administration's attempt to resist entrapment by establishing its intent to take sides without getting involved was a contributing variable to the trajectory of escalation.

Furthermore, as is typical in the first phases of entrapment, the U.S. and its allies gravely misperceived their proximity to the end of the conflict. They were operating under a misconception that Assad's fall was imminent, making a call for him to step aside a seemingly low-hanging fruit. As Joshua Landis claims, "the intelligence community was unanimous in predicting that Assad would fall quickly" and, hinting at the irrationality of the misperception, also admits "it was only natural that our aspirations would overtake fact-based analysis" (Landis 2017). The U.S. security apparatus expected Assad's fall to mimic something like those of Mubarak or Ben Ali, who stepped down after demonstrations escalated in Egypt and Tunisia, or the brutal overthrow of Qadaffi in Libya. Either way, at the outset of the conflict, the overarching consensus in Washington was that the Assad regime was simply the next domino to fall.

Hours after Obama's "Assad must go" statement, Angela Merkel, Nikolas Sarkozy and David Cameron, who until then were waiting in the wings for the U.S. to make clear its position on Assad, released similar statements denouncing the regime. At the time, insisting Assad step aside was a natural responsibility the U.S. was obliged to take as the leader of a unipolar world and a reputational investment. Renouncing rogue dictators with no utility to the United States - "playbook" or not - was part of a routine policy mechanism the Obama administration developed into a reflex during the Arab Spring. After the coalition of U.S., EU and Gulf states urged his surrender, Assad matched the global pressure with escalating brutality. Reciprocating the regime's resistance to international pressure, the Obama administration committed the U.S. and its foreign policy apparatus to the goal of removing Assad from power. The U.S. accepted Sarkozy's invitation to join the "Friends of Syria" - a group of more than 100 states invested in transitioning Assad out of power. In early in 2012, it led the coalition to recognize the National Council as the legitimate governing body that power would pass to after Assad's (perceived) fall. This, in tandem with Secretary Clinton's role in negotiating the UN-led Geneva Process, put the U.S. at the forefront of organizing the opposition, a responsibility it did not necessarily mind and one that it believed let it reach the perfect temperature of commitment.

Meerts refers to this as the "do something" effect, a dangerous trigger that can commit powerful nations and whole institutions to a course of entrapment (Meerts 2005). A low-level of involvement is a rational starting point for a party that perceives itself to be close to reaching a desired outcome. Decision makers assumed too much involvement or force could damage their trajectory - in 
this case, coalition decision makers assumed immediate military action could destabilize the society and create a security vacuum. On the other end of counterfactuals, decision makers also assumed that no involvement would come at a cost - in this case, a reputational one. It is not easy to calculate how much credibility the U.S. would have spent in avoiding the opportunity to call for Assad to step aside but this spectrum of options reveals the that uncertainty and lack of control that come with entrapping scenarios makes them, many times hard to avoid, but always even harder to disengage. The external powers' soft diplomatic engagement constituted the first phase of entrapment of goal identification and reward pursuit.

\section{Phase Two - Cost Justification, Escalation and Deadlock in Negotiation, 2012-2014}

When they start to play the dollar game, players do not know that the most optimal time for them to withdraw is right away. For states like the U.S. and its coalition with their reputation at stake, this was not an option, nor was backing away from the hard "Assad must go" line they drew in the sand. As Meerts importantly notes, "consistency in action is a more desirable leadership strategy than experimentation" and "many individuals would choose to remain committed to a dubious course of action simply because the opportunity to receive a positive evaluation by others would be greater in the case of consistency than with experimentation" (Meerts 2005). Despite enormous attempts to avoid deep engagement, the U.S. and its allies were pulled into the riptide of the Syrian civil war by their attempt to vindicate the reputational costs they sunk into their initial reward pursuit. This escalation constitutes the next phase of entrapment: cost justification.

After the U.S. and other moderate opposition backers made their goal of empowering a transitional government clear, and made initial reputational investments by backing the opposition in diplomatic fora and imposing sanctions on the regime, they struggled to see their investments pay off. The regime maintained strong, though still defensive, footing with support from Russia and Iran. Russia supplied a steady flow of arms and financing while preventing UNled arms boycotts to the Assad regime in 2013 (Phillips 2018: 98). Iran extended a $\$ 3.6$ billion line of credit to the regime in July 2013 (EIU 2015). Between 2012 and 2013, regime forces were able to consolidate and mobilize chemical weapons which they used in a series of attacks that gravely escalated the war.

The U.S. responded in several layers of escalation that deepened its commitment to the opposition and removing Assad from power. In 2012, the US began to monitor on the ground flow of arms and financing from Gulf States, in an attempt to traffic material to only moderate forces. In 2013, the Obama 
administration approved and implemented a revision to the covert program, Timber Sycamore, committing to arm and equip the rebels with the sole purpose of removing Assad from power. The program would quickly become one of the most expensive covert programs in CIA history, amounting to over $\$ 1$ billion a year (Lund 2017). The increased investment reflects a new level of U.S. commitment to its original position and its attempt to justify and protect the reputational costs it already put on the line when it supported the opposition in diplomatic efforts.

In entrapping scenarios, the scope of what each party is willing to agree to in a negotiated peace settlement will change over time. The party with less to lose, and so, a bargaining disadvantage, will experience an increase in its zOPA and a decrease in its BATNAs. The Syrian Civil War's peace efforts provide reliable evidence of this effect for two main reasons. First, peace efforts continued from the very beginning of the conflict through to the present day, and so, provide clear and consistent insight into each counterparty's positions during each part of the war. This makes it easy to evaluate how each party's commitment to original positions changed over time. Second, there were several parallel peace efforts, which leaves ample evidence and accounts for a diversity in variables. For the purposes of this case study, it is best to focus on how outcomes and positions in the UN-led Geneva process changed throughout the course of the war and to study the dynamics and objectives of the Astana process which developed during the later phases of entrapment. This case specifically compares the outcomes from the process during the reward pursuit and cost justification phases with outcomes from the punishment and loss minimization and goal relinquishment phases. What follows is a discussion negotiation outcomes from the first two phases of entrapment where the US and its allies, entrenched in an "Assad must go" posture, were met by disproportionately recalcitrant regime sponsors unwilling to bend on their own "Assad must stay" stance.

Since the outbreak of the Syrian civil war, four different mediators - the Arab League, United Nations (under 3 different special envoys), Russia, and the International Syria Support Group (ISSG) chaired by both Russia and the United States - have hosted nine ${ }^{2}$ different peace processes resulting in dozens of conferences, countless talks and zero tangible outcomes. The Geneva II talks, managed to bring regime and opposition forces into the same room for the first time in late 2012, but besides this, almost no headway has been made

2 These include (1) the Arab League I and II agreements, (2) the Annan 6-Point Plan, (3) the Geneva Process, (4) the Moscow Conferences, (5) the Cairo Conferences, (6) the Astana Conferences, (7) the Vienna Talks, (8) the Riyadh Conference and (9) the Munich Conference. 
in getting the two sides to negotiate a peace settlement. It is reasonable to assume that the absence of a mutually hurting stalemate is to blame. But it is almost unfathomable that, with staggering casualties on both sides, parties had not felt mutual pressure to pursue a way out of this crisis. This is an indication that outside sponsors fell prey to a period of entrapment, incrementally deepening their investments in tandem with increased entrenchment in their negotiating positions.

The parameters and scope of the agreements discussed in the various phases of negotiation efforts gradually changed over time, but in the first phase comprised of the Arab League's initial efforts, Annan's 6-Point Plan and the Geneva I and II conferences - all sponsors remained entrenched in their initial negotiating posture, starkly supporting or opposing Assad's removal from the transitional governing body the negotiations endeavored to build.

In February 2012, Kofi Annan drafted his 6-Point-Plan draft which deliberately excluded any explicit mention of Assad's role in a future government focusing mainly on non-political items. However, disagreement among external actors over his mandate led to a breakdown in talks that revealed no overlap in each sides' projected solutions. Western diplomats believed Annan's mandate "was to engineer Assad's departure" and not, as others believed, "to create a framework for peace" (Phillips 2018: 100). The breakdown of support signaled a new degree of entrenchment that would only worsen in the UN-led Geneva process, instituted on the back of Anan's 6-Point Plan.

The Geneva Communique, signed in June 2012, at first blush, seemed like a promising step towards compromise. It provided mechanisms to implement Annan's 6-Point Plan, and notably attempted to bridge the gaping division between negotiating parties on Assad's place in a transitional government. It specifically called for a transfer of power to a transitional governing body with full executive authority composed of, in the language of the Communiqué itself, "members of the government and opposition and other groups [which] should be formed on the basis of mutual consent" (Geneva Communique 2012, Bick \& Roman 2017). However, the ambiguous nature of this language gave each party to the Communiqué veto power leading again to a predictable impasse.

Geneva II was the final point to plot the failing trajectory of the UN-led peace process. It was the last time negotiations seriously undertook the debate on Assad's place in a transitional government. But, as expected, the regime showed no commitment to the conference from the outset, preferring to escalate its on-the-ground efforts over pursuing a serious negotiation. Some consider Geneva II to have accomplished a small suite of achievements: the talks did mark the first time the regime and opposition sat at the same table since the onset of the war and the regime was cajoled into allowing an evacuation of 
women and children from the city of Homs (Hinnebusch \& Zartman 2016: 16). However, the rounds of discussion Brahimi organized on a transitional government collapsed after 30 minutes and in central talks the regime insisted discussion center on combatting terror groups, the definition of which it conveniently expanded to include most opposition militias, leaving negotiations just as stalemated as the actual war (idem).

Without a zone of possible agreement (zOPA) between the regime and opposition and either proxies' backers, the accomplishment of bringing both parties to the table meant relatively little. Brahimi himself knew how insurmountable the recalcitrance of the Assad regime and the disorganization of the opposition would be without encouragement from each side's external backers. During negotiations, he insisted to Russian and American diplomats: "I will not be able to get anything serious from your friends unless you convince them seriously of the need to look for a solution and that means making compromises" (Bick \& Roman 2017). But the external parties themselves were content with the impasse created by the actors' refusal to cooperate, prioritizing their own strategic desires as the talks unraveled. Just two weeks after the close of Geneva II, Russia annexed Crimea, effectively closing the door on the diplomatic progress it made negotiating with the U.S. to remove the regime's chemical weapons stockpiles and setting a new course for its regional ambition, one that would come at a high cost. The initial lack of compromise corresponds to various points of escalation that served as the negotiating parties' BATNAs.

\section{Phase Three - Turning Points: Punishment and Loss Minimization, 2014-2016}

The third phase of entrapment triggers a turning point, a plateau in the conflict where one or both parties realize the failing trajectory of their investments. At this point, entrapped parties perceive an increased importance in goals that either punish the adversary, minimize overall losses or both. While these goals are not mutually exclusive, in the case of the Syrian civil war, Russia increased the importance of goals that punished the adversary while the US increased the importance of goals that minimized losses.

In 2014, Putin initiated offensive Russian foreign policy and military campaigns meant to reset the balance of power in the region (Trenin 2015). Until then, despite deadlock in the Geneva Process, the U.S. and Russia maintained a relatively cooperative diplomatic relationship as they negotiated the removal of the regime's chemical weapon stockpile. This diplomatic détente came was destroyed when Putin mobilized a military campaign annexing Crimea in February 2014 and in 2015 surged support to the Assad regime which by that point was on its heels. Russia mobilized its air force and increased its 
on-the-ground-presence to 2,00o troops (Philips 2018: 217). The Russian surge allowed the regime to regain significant amounts of rebel-held territory in Aleppo, Damascus, Rabia and Dera'a, the original seat of the revolution. The surge decisively tipped the scales in Assad's favor, not enough to declare a conclusive military victory, but certainly in a way that gave Assad a concrete advantage in negotiations (Philips 2018: 219).

Meanwhile, the EU and U.S. took actions to minimize their losses. They began to distance themselves from an inflexible "Assad must go" posture for three reasons. First, the massive influx of migrants that resulted from the civil war created a humanitarian disaster at the EU's doorstep, sparking political turbulence that EU leadership could not justify with continued commitment to its trajectory supporting Syrian rebels. At the same time Europe was suffering from the political and economic ramifications of a migrant crisis, the dynamic between the U.S. and Iran had fundamentally changed. The U.S. was in the midst of negotiating the JCPOA with Iran and did not want to disturb its tenuous progress. In order to avoid giving Iran the opportunity to use the Syrian talks as leverage, the White House distanced itself from the peace process and allowed its commitment to its original "Assad must go stance" stance to bend. The Obama administration could not justify short-changing progress on the Iran deal for increased influence in the Syrian negotiations. Lastly, the U.S. and EU had no one left to back in the peace effort. The "moderate opposition," had never truly amalgamated into one organized front, and although by 2015 its negotiators created the High Negotiation Committee (HNC) - which notably excluded Kurdish forces - on the ground its militias splintered into unsalvageable pieces. Blemished by its increased cooperation with radical groups, the nebulas opposition was no longer recognizable as a conceivable ally in a war against Assad or IsIs for that matter. The lack of leadership alternatives inherent in the opposition made arguing for Assad's departure almost illogical. In other words, the U.S. and EU began to perceive a continued entrenchment in their original positions as incurring costs they knew would not return their investments and so resorted to a loss minimization strategy.

On the other end of Russia's decisive military involvement and the rebel sponsor's pivot to loss minimization, international peace efforts took on a new form. The UN-led Geneva process shifted its focus from the political objective of creating a transitional government to humanitarian agreements focused on aid, ceasefires and safe-zones. Furthermore, Russia and Iran worked to create a newly assembled peace effort, the Astana Process, that would fall squarely into their increasingly powerful orbit. The shift in negotiation scope signals parties reached the final phase of entrapment, goal relinquishment - at the onset of Geneva III. 


\section{Phase Four - Goal Relinquishment and Parallel Peace Efforts, 2015 Onward}

Moving goal posts to accommodate a lower level of commitment indicates the final phase of entrapment, that of goal relinquishment. After the series of tipping points that occurred between 2014 and 2015, the United States and other opposition backers began to indicate they were willing to rollback their initial objective of removing Assad from power. On October 4, 2015, British Foreign Secretary Philip Hammond claimed the UK would concede to allowing Assad to "remain as the titular head of state for a period of time" if it meant achieving a negotiated peace (James 2015). Although the Obama administration had first signaled a tolerance of Assad's legitimate role in power during its negotiations with the regime and Russia to remove chemical weapons, it was not until December 2015 that the administration, in the form of a short address by Secretary Kerry, came out to announce that the U.S. and its partners were "not seeking so-called regime change," in Syria (Klapper \& Lee 2015). This combination of increased support from Assad's backers and compounding pressures on the US and its alliance shook the conflict out of a stalemate and into the regime's favor. Correspondingly, in the ongoing negotiation rounds, the zOPA had decisively shifted.

As Phillips puts it, once Russia "raised the stakes to a level that Western leaders ...were unwilling to match, a climbdown was required" (Phillips 2018: 224). This climbdown first manifested itself in the Vienna Process, marking a de-escalatory phase in the conflict. Launched on November 14, 2015, The Vienna Process was a joint effort by the United States and Russia to revive the faltering UN-led Geneva process with which it drew several notable differences. First Russia and the United States co-chaired the talks and worked jointly to build the process' ISSG which included almost all actors in the conflict except the Syrian government and the opposition themselves. The group also welcomed Iran as a member, not only allowing it to participate in talks that would give it a degree of influence in the tangential Geneva process, but legitimizing it as stakeholder in post-conflict outcomes.

The first round of talks produced an actionable plan pursuant to the 2012 Geneva Communique and aimed to convene representatives from the Syrian Government and opposition to deliberate on a "Syrian-led and Syrianowned" political process and also, markedly, insisted state institutions would "remain intact," (Vienna Communique 2015) an item that could be viewed as favorable to the Syrian government. The second round of talks promised yet another conference to negotiate a ceasefire and a parallel talk to draft a new constitution. However, neither of the statements nor the UN resolution adopting them indicated what role Assad would play in the political 
transition, leaving the Vienna process with the same ambiguity that plagued the efforts before it. The talks eventually gave way to the shape-shifting Geneva Process which ultimately never broached the topic of a new government without Assad again.

\section{A Zone of Possible Agreement among a New League of}

Negotiators - The Astana Process

The tail end of Russian escalation clearly defined a pivot in the course of the war. Not only had Russia's support helped the regime to regain $15 \%$ of rebel territory (Phillips 2018: 239), the fall of eastern Aleppo allowed Russia and its alliance to build a new peace process centered on their interests that would ultimately threaten to eclipse the Geneva talks and reveal how severely the scales had tipped. On the back of the December 2015 ceasefire brokered by Turkey, Russia galvanized support to host a new peace effort in Astana, the capital of Russia's backyard-satellite-state, Kazakhstan.

The talks were rooted in political objectives that would favor its guarantors. The first round convened leaders from only 30 "Ankara friendly" opposition groups. In May 2015 it produced the "Astana Declaration for a Political Solution in Syria," which indoctrinated the broader Astana process as one that would focus on constructing safe zones but also consider political solutions (Kazakhstan Embassy 2018). But the process also served Assad's backers with an opportunity to prop up the opposition groups they believed would be easy to manipulate and to narrow the scope of who could be considered a legitimate negotiating partner. Turkey protested the inclusion of any Kurdishrelated militia, despite the fact they had emerged as the US' more reliable ally in the war and were gaining meaningful resource-rich territory that could be used as a bargaining chip in a negotiation. Iran also used a broad definition of "terrorist" to exclude what others would consider to be reputable groups from receiving an invitation (Lund 2017).

Some scholars following the peace effort suggest that Astana's separation from the UN-led Geneva process makes it less legitimate. While, as Lund suggests, the talks were an "improvised gamble to exploit sudden opportunities" or as Heller puts it, "skewed more towards grubby deal-making," - both of which are fair interpretations of the Astana conferences' personality - it is important not to evade the truth (Lund 2017). The talks became a serious counterweight to the Geneva Process and provided a legitimate option for the Assad Regime to consider when deliberating which process to take seriously from the everextending menu of parallel efforts. Importantly, the Astana process was the first parallel peace effort that would convene to de-escalate the war with Assad in place. 


\section{Geneva III and IV and the First Indications of Intractability}

The U.S. and its allies subtly moved the goal-posts as they were no longer interested in negotiating a transitional government free of Assad. This became apparent first in the Geneva III conference organized by Stefan de Mistura in February 2016 who focused the talks on simple non-political goals "more modest" than any of the ones Brahimi had outlined in early talks or Annan in the talks before that (Phillips 2018: 228). The conference ended after three days when the HNC walked out to protest the regime's most recent advance in Aleppo, citing it as an example of the regime "disrespecting the process," but in an emerging pattern of cooperation, the US and Russia resurrected the talks later that month to negotiate a cessation of hostilities, and deliver relief supplies (Phillips 2018: 228-229). The Syrian Observatory for Human Rights claimed the ceasefire resulted in the most peaceful period in the 6-year war, with the month after its negotiation boasting the lowest civilian causalities since November 2011 (Phillips 2018: 229).

The non-political objectives of the talks were what allowed the cessation of hostilities to succeed; humanitarian goals were low-hanging fruits for Russia to accept and cajole the regime into implementing. But this signaled a broader shift in the Geneva talks' purpose. In referring to Geneva IV, Lund emphasizes this point claiming that, "by shifting focus to incidental political arrangements, the UN subtly de-emphasized the irreconcilable disputes over how to interpret transitional language inherited from 2012," and thereby allowed the "prospect of a peace process" that would keep Assad in power (Lund 2017a). There have been nine rounds of Geneva peace talks in total, the last ending in November 2017. None since Geneva II put discussion of a transitional government on the agenda.

The outcomes of the variety of peace efforts that began or continued after 2015 indicated the opposition and its backers changed the fundamental objectives governing their involvement in the war. The US was no longer interested in removing Assad from power, having reached what Mitchell refers to as a "certain point" where "the influence on judgement of the level of sunk costs seems to change" and where "the weight of the sacrifices already made added to those being suffered ...become mutually reinforcing influences on the evaluation of the utility of seeking a victorious outcome" (Mitchell 1991).

\section{Research Limitations}

There are a few concession statements that should be made in order to define the limitations of how entrapment applies to intractability and how the Syrian civil war highlights the areas in the study of entrapment that warrant more attention from scholars. First, it should be noted that in the case of the 
Syrian Civil War, entrapment as a phase of intractability seems to apply more to external actors than the conflicts' core parties and that those on-the-ground combatants likely came close to "feeling" a mutually hurting stalemate at several points throughout the war. However, constant support from external sponsors made reaching a stalemate - by the depletion of resources - almost impossible. While we note the psychological underpinnings of entrapment in external and regional sponsor behavior, it is clear that different parties at different levels of involvement experience different costs - measured in reputation, human lives, finances - and that these warrant a more nuanced analysis. Entrapment in proxy wars calls for further study.

It is also important to recognize the limitations of applying behavioral theories developed in across the economic and psychology disciplines for level one analysis to state behavior. For the purpose of the case study, it is understood that a state's foreign policy is largely decided by its executive branch and/or head of state but there are consequential differences in decision-making and strategy implementation between theocracies and democracies and states with large institutions versus those with concentrated power. Between states there are also varying degrees of groupthink and varying degrees of a leader's openness to dissent. Designing a case study around such an interdisciplinary approach requires applying the most broad and basic deductions from other fields.

Lastly, it is possible to dwell on some parts of this analysis to suggest that the U.S. and its allies were not entrapped in the Syrian civil war and that instead this case study is just one of pure intractability and not worth a deeper examination. For instance, one might argue that the U.S. resisted the entrapping momentum of the conflict from the start when Obama declined to follow the typical "Washington playbook" refusing to threaten the Assad regime with a military intervention. Similarly, one might suggest the administration resisted ownership of another quagmire when it refused to carry-out Libyan-style airstrikes preferring to negotiate directly with its opponents, Russia and Assad, in September 2013 (in that case to remove the regime's stockpiled chemical weapons). As a result of these negotiations the Obama administration inadvertently legitimized the Assad regime, which seems to counter any claims made suggesting the US and its allies were deeply committed to removing Assad from power throughout the course of the several peace efforts.

However, these elements capture some of the most intangible but important characteristics of entrapment and reveal that entrapment comes in varying degrees. First they reveal a "big power problem" a phenomenon Meerts describes as one where "more powerful countries often overestimate themselves which can lead to their entrapment by the weaker party" (Meerts 2005). In the 
context of the Syrian civil war, the U.S. overestimated its ability to counter Assad and its backers, underestimated the regime's commitment and as a result consistently misperceived its proximity to the goal of replacing Assad and his regime with new political leadership. Its negotiating with Assad the White House signaled confidence in this trajectory and confidence in its initially low "investment" in diplomatic and military commitments. This misperception might have helped the Opposition's backers to evade deep commitments upfront, but it also trapped them into making small increases over time which not only escalated their involvement but prolonged the war and increased net costs.

\section{Conclusion}

We live in the midst of a series of intractable conflicts that owe their arc of escalation to a phase of entrapment. Conflicts such as the ongoing wars in Afghanistan and Iraq, and the continuing conflicts in Cyprus and Kashmir exhibit a unique combination of qualities that suggest prior to reaching the final phase of intractability the parties involved were entrapped. There is no case, however, more pertinent and illustrative of the intricacies of entrapment in intractable conflict than the Syrian civil war which unearths a series of lessons for external actors involved, all of which have been counting sunk costs, underestimating risk and escalating commitment to a path they had already invested in despite that path's increasing potential to fail. The Syrian civil war as a case study of entrapment not only sheds light on those symptoms of entrapment that make the phase easy to diagnose such as a change in the motivation and a change in objectives, but it also illuminates those exogenous elements such as the level of uncertainty or unpredictability in a conflict or how the relative losses or gains one party can make can increase a state's vulnerability to entrapment.

Recognizing the consequences of entrapment in categorizing a conflict's identity can provide policymakers with the tools they need to extract themselves from an entrapping or intractable conflict before the conflict reaches a phase of institutionalization. As such, this case study is illustrative in nature and seeks to highlight what Rubin, Brockner and Meerts posit are the main symptoms of entrapment in a real-world conflict and how these signals emerge through the four phases posited by Mitchell. It begins by assessing each party's prospective gains and losses and how the motivations each party had for getting involved in the conflict changed as they escalated involvement. It further identifies examples of misperceived proximity to goals and the resulting 
underinvestment bid by the Opposition's sponsors. It also confronts the idea the more entrapped party in a conflict will ultimately be the one to change its posture in negotiations or desert the negotiation process all together. In so doing, this study maps the positions state sponsors and parties to the conflict take in the various negotiation processes alongside their increasing investments in the conflict to chart the arc of entrapment and show that over time the party with less to lose - and so perhaps more entrapped - will move the dial in negotiations and forfeit precious space in the zone of possible agreement (ZOPA) bringing the conflict towards a steady state of institutionalization.

In sum, the present study posits that intractability in escalating conflicts is contingent upon decisions that parties make along the way and their inability to anticipate the implications of their escalatory measures. Previous studies have identified failed peace-making processes as an essential characteristic of intractable conflicts which have the quality of reducing the appeal of a negotiated solution. This study, however, shows that successful peacemaking understood as the achievement of an agreement does not reduce the propensity of that conflict to become intractable. In fact, due to entrapment dynamics, choices that parties can make in negotiating an agreement can lead to an institutionalization of the conflict through a peace settlement. As such, in order to avoid intractability, it is not enough if a negotiated solution is sought, rather it is imperative to identify solutions that downplay entrapment dynamics and reverse the psychological drivers that have justified over-commitment and overinvestment in the conflict in the first place. A genuine ripe moment that can contribute to conflict resolution, is contingent upon each party addressing the consequences of the escalatory measures they put in place and relinquishing goals they set that trapped them in conflict in initial phases of entrapment.

\section{References}

Asher-Schapiro, A. (2016). "The Young Men Who Started Syria's Revolution Speak about Daraa, Where It All Began." Vice News. March 15. At: https://news.vice.com/en_us/ article/qv5eqb/the-young-men-who-started-syrias-revolution-speak-about-daraa -where-it-all-began.

Azar, E. E. (1990). The Management of Protracted Social Conflicts: Theory and Cases. Aldershot: Dartmouth Publishing Company.

Bar-Tal, D., L. Chernyak-Hai, N. Schori, and A. Gundar (2009). "A Sense of Self-Perceived Collective Victimhood in Intractable Conflicts." International Review of the Red Cross 91, 874: 229-258. 
$B B C$ (2012). “Analysis: Syria's 'intractable' conflict.” April 12. At: https://www.bbc.com/ news/world-middle-east-18420858.

Bick, A. and L. Roman (2017). "It's Time for a New Syria Peace Process." Foreign Policy, September 15 .

Bowen, M. G. (1987). "The Escalation Phenomenon Reconsidered: Decision Dilemmas or Decision Errors?" Academy of Management Review 12, 1: 52-66.

Brockner, J. (1992). "The Escalation of Commitment to a Failing Course of Action: Toward Theoretical Progress." Academy of Management Review 17, 1: 39-61.

Brockner, J. and J. Z. Rubin (1985). Entrapment in Escalating Conflicts: A Social Psychological Analysis. New York: Springer Science \& Business Media.

Burt, A. (2018). Deal Making and Peace Building: A New Approach to Reducing Conflict. Speech from Minister for International Development Alistair Burt at Chatham House. At: https://www.gov.uk/government/speeches/deal-making-and -peace-building-a-new-approach-to-reducing-conflict.

Burton, J. W. (1987). Resolving Deep-Rooted Conflict: A Handbook. Lanham, MD: University Press of America.

Cameron, K. S. and R. E. Quinn (1988). Organizational Paradox and Transformation. Pensacola, FL: Ballinger Publishing Co/Harper \& Row Publishers.

Chulov, M. (2018). “Moscow Mired in Syria as Putin's Gameplan Risks a Deadly Ending.” The Guardian. February 24. At: https://www.theguardian.com/world/2018/feb/24/ russia-putin-syrian-war-intervention-assad-ghouta-turkey-iran?CMP=share_btn_fb.

CNBC (2015). "Syria's Increasingly Intractable Conflict." October 2. At: https://www .cnbc.com/video/2015/10/02/syrias-increasingly-intractable-conflict.html.

Coleman, P. T. (2003). "Characteristics of Protracted, Intractable Conflict: Toward the Development of a Metaframework-I." Peace and Conflict:Journal of Peace Psychology 9, 1: $1-37$.

Coleman, P. T. (2006). "Intractable Conflict," in M. Deutsch, P. Coleman, and E. Marcus, editors, The Handbook of Conflict Resolution: Theory and Practice. San Francisco: Jossey Bass.

Corstange, D. and E. A. York (2018). "Sectarian Framing in the Syrian Civil War." American Journal of Political Science 62, 2: 441-455.

Crocker, C. A., F. O. Hampson, and P. R. Aall (2005). Grasping the Nettle: Analyzing Cases of Intractable Conflict. Washington, D.C.: US Institute of Peace Press.

Diehl, P. F., editor (1998). The Dynamics of Enduring Rivalries. Champaign, IL: University of Illinois Press.

Di Giovanni, J. (2018). “There's a Right Way to End Syria's War: The New Special Envoy Must Not Allow Russia to Protect Assad." Foreign Affairs. November 14.

Edmead, F. (1971). Analysis and Prediction in International Mediation (No. 2). United Nations Institute for Training and Research. 
Erameh, N. I. (2017). "Humanitarian Intervention, Syria and the Politics of Human Rights Protection." The International Journal of Human Rights 21, 5: 517-530.

Esfandiary, D. (2018). No Country for Oversimplifications: Understanding Iran's Views on the Future of Regional Security Dialogue and Architecture. The Century Foundation. January 24. At: https://tcf.org/content/report/no-country-oversimplifications/.

European Parliament (2016). “Hell on Earth:' MEPs Debate Aleppo and Role of Russia in Syria Conflict." At: http://www.europarl.europa.eu/news/en/headlines/ society/2016o93oSTO44539/hell-on-earth-meps-debate-aleppo-and-role-of-russia -in-syria-conflict.

Fisher, R. J. (2006). "Intergroup Conflict," in M. Deutsch, P. Coleman, and E. Marcus, editors, The Handbook of Conflict Resolution: Theory and Practice. San Francisco, CA: Jossey Bass.

Forde, S. (2004). "Thucydides on Ripeness and Conflict Resolution." International Studies Quarterly 48, 1: 177-195.

Fortna, V. P. (2003). "Scraps of Paper? Agreements and the Durability of Peace." International Organization 57, 2: 337-372.

Galtung, J. (1969). "Violence, Peace, and Peace Research.” Journal of Peace Research 6, 3: $167-191$.

Geneva Communiqué. (2012). United Nations. At: http://www.un.org/News/dh/ infocus/Syria/FinalCommuniqueActionGroupforSyria.pdf.

Goertz, G. and P. F. Diehl (1993). "Enduring Rivalries: Theoretical Constructs and Empirical Patterns." International Studies Quarterly 37, 2: 147-171.

GOV UK (2018). "Deal Making and Peace Building: A New Approach to Reducing Conflict."

Greig, J. M. (2013). "Intractable Syria-Insights from the Scholarly Literature on the Failure of Mediation." Penn State Journal of Law \& International Affairs 2, 48.

Gurr, T. R. (2000). Peoples Versus States: Minorities at Risk in the New Century. Washington, DC: US Institute of Peace Press.

Hassner, R. E. (2007). The Path to Intractability: Time and the Entrenchment of Territorial Disputes. International Security 31, 3:107-138.

Hinnebusch, R. and I. W. Zartman (2016). UN Mediation in the Syrian Crisis: From Kofi Annan to Lakhdar Brahimi. International Peace Institute.

Human Rights Watch (2018). Syria: Events of 2017. At: https:/www.hrw.org/sites/ default/files/syria_2.pdf.

James, W. (2015). "Russia is Conducting 'Asymmetric Warfare' in Syria." Reuters. October 4. At: https://www.reuters.com/article/uk-mideast-crisis-syria-britainhammond-idUKKCNoRYoQ520151004.

Jenkins, B. M. (2014). The Dynamics of Syria's Civil War. RAND. At: https://www.rand .org/pubs/perspectives/PE115.html. 
Jones, S. G. (2013). “Syria's Growing Jihad." Survival 55, 4: 53-72.

Kazakhstan Embassy (2018). Kazakhstan Hosts Syrian Opposition Meeting in Search of Peace: Press Release. May 2018. At: https://www.kazakhembus.com/content/ astana-hosts-syrian-opposition-meeting-search-peace.

Kelman, H. C. (1999). "The Interdependence of Israeli and Palestinian National Identities: The Role of the Other in Existential Conflicts." Journal of Social Issues 55, 3: 581-60o.

Kerry, J. (2015). Remarks on the U.S. Strategy in Syria. U.S. Department of State. November 12. At: https://2009-2017.state.gov/secretary/remarks/2015/11/249454.htm.

King, C. (2007). "Power, Social Violence, and Civil Wars," in C. Crocker, F. Hampson, and P. Aall, editors, Leashing the Dogs of War: Conflict Management in a Divided World. Washington, DC: United States Institute of Peace.

Klapper, B. and M. Lee (2015). "Assad Can Stay for Now: Kerry Accepts Russian Stance." Military Times. December 16. At: https://www.militarytimes.com/news/ your-military/2015/12/16/assad-can-stay-for-now-kerry-accepts-russian-stance/.

Kriesberg, L. (2005). "Nature, Dynamics, and Phases of Intractability," in C. A. Crocker, F. O. Hampson and P. Aall, editors, Grasping the Nettle: Analyzing Cases of Intractable Conflict. Washington, DC: US Institute of Peace Press.

Kriesberg, L. (2007). Constructive Conflicts: From Escalation to Resolution. Lanham, MD: Rowman \& Littlefield.

Landis, J. (2017). “America's Failure - and Iran and Russia's Success - in Syria's Cataclysmic Civil War." Talking Points Memo (J. Judis, Interviewer). At: https://talkingpoints memo.com/cafe/americas-failure-russia-success-in-syrias-war.

Leininger, W. (1989). "Escalation and Cooperation in Conflict Situations: the Dollar Auction Revisited." Journal of Conflict Resolution 33, 2: 231-254.

Lund, A. (2017). "How Assad's Enemies Gave Up on the Syrian Opposition." The Century Foundation. At: https://tcf.org/content/report/assads-enemies-gave-syrian -opposition/.

Lund, A. (2017). Staring into Syria's Diplomatic Fog. The Century Foundation. At: https:// tcf.org/content/commentary/staring-syrias-diplomatic-fog/.

Lund, A. (2017). "Everything You Need to Know About the Latest Syria Peace Talks: Geneva IV: Who is Coming? What do They Want? And Will it Matter?" IRIN. February 21. At: https://www.irinnews.org/analysis/2017/02/21/everything-you-need -know-about-latest-syria-peace-talks.

Lundgren, M. (2016). "Mediation in Syria: Initiatives, Strategies, and Obstacles, 20112016." Contemporary Security Policy 37, 2: 273-288.

McEvers, M. (2012). "Revisiting the Spark That Kindled The Syrian Uprising." NPR. March 16. At: https://www.npr.org/2012/03/16/148719850/revisiting-the-spark -that-kindled-the-syrian-uprising. 
Meerts, P. W. (2005). "Entrapment in international negotiations," in I. W. Zartman and G. O. Faure, editors, Escalation and Negotiation in International Conflicts. Cambridge: Cambridge University Press, pp. 111-141.

Miller, P. D. (2014). Getting to Negotiations in Syria: The Shadow of the Future and the Syrian Civil War. RAND. At: https://www.rand.org/pubs/perspectives/PE126.html.

Mitchell, C. R. (1991). "Ending Conflicts and Wars - Judgement, Rationality and Entrapment." International Social Science Journal 43, 1: 35-55.

Mitchell, C. R. (1995). “The Right Moment: Notes on Four Models of 'Ripeness.” Global Society: Journal of Interdisciplinary International Relations 9, 2: $3^{8-52 .}$

Mitchell, C. R. (2005). Conflict, Social Change and Conflict Resolution: An Enquiry. Berghof Research Centre for Constructive Conflict Management. At: https://www .berghof-foundation.org/fileadmin/redaktion/Publications/Handbook/Articles/ mitchell_handbook.pdf.

O’Neill, B. (1986). "International Escalation and the Dollar Auction." Journal of Conflict Resolution 30, 1: 33-50.

Oosterveld, W. (2018). "Does the EU have a Syria Strategy?" EU Observer. At: https:// euobserver.com/opinion/141249.

Pearce, W. B. and S. W. Littlejohn (1997). Moral Conflict: When Social Worlds Collide. New York: Sage.

Phillips, C. (2015). "Sectarianism and Conflict in Syria." Third World Quarterly, 36, 2: $357-376$.

Phillips, C. (2018). The Battle for Syria: International Rivalry in the New Middle East. New Haven: Yale University Press.

PRI (2015). "Syria: How it All Began." Public Radio International. March 16. At: https:// www.pri.org/stories/2011-04-23/syria-how-it-all-began.

Pruitt, D. G. (2005). "Escalation, Readiness for Negotiation, and Third-Party Functions," in I. W. Zartman and G. O. Faure, editors, Escalation and Negotiation in International Conflicts. Cambridge: Cambridge University Press.

Richmond, O. (1998). "Devious Objectives and the Disputants' View of International Mediation: A Theoretical Framework." Journal of Peace Research 35, 6: 707-722.

Rinne, J. (2018). Conflict Mapping and the Syrian Civil War. Conflict Analysis Research Centre, University of Kent. At: https://blogs.kent.ac.uk/carc/2018/02/11/ conflict-mapping-and-the-syrian-civil-war/.

Rubin, J. Z., D. G. Pruitt, and S. H. Kim (1994). Social Conflict: Escalation, Stalemate, and Settlement. New York: McGraw-Hill Book Company.

Sharp, J. M., and C. M. Blanchard (2011). "Unrest in Syria and US Sanctions against the Asad Regime." Congressional Research Service, 4.

Shubik, M. (1971). "The Dollar Auction Game: A Paradox in Noncooperative Behavior and Escalation." Journal of Conflict Resolution 15, 1: 109-111. 
Teger, A. I. (1980). Too Much Invested to Quit. New York: Pergamon Press.

The Economist (2016). "Syria's War: Never-Ending Horror." At: https://www.economist .com/middle-east-and-africa/2016/06/04/never-ending-horror.

The Economist Intelligence Unit (2015). "Syria: Country Outlook." May 20. At: http:// viewswire.eiu.com/index.asp?layout=VWArticleVW3\&article_id=803182864.

The New York Times (2011). "In Syria, Crackdown after Protests." March 18. At: https:// www.nytimes.com/2011/03/19/world/middleeast/19syria.html.

The Washington Post (2016). "Obama's End-of-Year News Conference on Syria, Russian Hacking and More." Transcript, December 16. At: https://www.washingtonpost .com/news/post-politics/wp/2016/12/16/transcript-obamas-end-of-year-news - conference-on-syria-russian-hacking-andmore $/$ ? noredirect $=$ on $\&$ utm _term $=.284 \mathrm{e} 4536 \mathrm{bde} 5$.

The World Bank (2017). "The Toll of War: The Economic and Social Consequences of the Conflict in Syria." July 10. At: https://www.worldbank.org/en/country/ syria/publication/the-toll-of-war-the-economic-and-social-consequences-of-the -conflict-in-syria.

Trennin, D. (2015). "Putin's Syria Gambit Aims at Something Bigger than Syria." October 13. Tablet. At: https://carnegie.ru/2015/10/13/putin-s-syria-gambit-aims-at -something-bigger-than-syria-pub-61611.

UNHCR (2017). Global Trends: Forced Displacement in 2017. At: https://www.unhcr .org/5b27be547.pdf.

UNSG (2015). "Vienna Communiqué on Syria: October 30, 2015." At: https://www .un.org/sg/en/content/sg/note-correspondents/2015-10-30/note-correspondents -vienna-communique-syria.

Volkan, V. D. (1988). The Need to Have Enemies and Allies: From Clinical Practice to International Relationships. Lanham, MD: Jason Aronson.

Walter, B. F. (2003). "Explaining the Intractability of Territorial Conflict." International Studies Review 5, 4: 137-153.

Zartman, I. W. (2001). "Negotiating Internal Conflict: Incentives and Intractability." International Negotiation 6, 3: 297-302.

Zartman, I. W. (2005a). "Analyzing Intractability," in C. A. Crocker, F. O. Hampson, and P. R. Aall, editors, Grasping the Nettle: Analyzing Cases of Intractable Conflict. Washington, DC: US Institute of Peace Press.

Zartman, I. W. (2005b). "Structures of Escalation and Negotiation," in I. W. Zartman and G. O. Faure, editors, Escalation and Negotiation in International Conflicts. Cambridge: Cambridge University Press.

Zartman, I. W. and G. O. Faure (2005). "The Dynamics of Escalation and Negotiation," in I. W. Zartman and G. O. Faure, editors, Escalation and Negotiation in International Conflicts. Cambridge: Cambridge University Press. 